\title{
Seedbed effects on grass establishment on abandoned Neb- raska Sandhills cropland
}

\author{
MILTON A. KING, STEVEN S. WALLER, LOWELL E. MOSER, AND JAMES L. STUBBENDIECK
}

\section{Abstract}

Perennial grass establishment on abandoned cropland in the Nebraska Sandhills is difficult due to low soil fertility, organic matter, and water holding capacity and high potential erodibility. Establishment is further complicated by unpredictable precipitation and weed competition. Two warm-season grasses: sand bluestem [Andropogon gerarditi var. pauctpllus (Nash) Fern.] and switchgrass (Panicum virgatum L.); and 2 cool-season grasses: smooth brome (Bromus inermis Leyss.) and intermediate wheatgrass [Thinopyrum intermedium (Host) Barkw. \& D.R. Dewey subsp. intermedium/ were evaluated with spring-seeded field trials. Seedbed preparation [untilled, disced, and dead oat (Avena sativa L.) cover (DOC)] effect on seeded grass and nonseeded species densities was evaluated in 1985 and 1986 at 2 locations on Valentine sands (Aquic Ustipanmment). In 19851 site was irrigated. Both sites were dryland in 1986. Stand failure $\left(<5\right.$ seedlings $\left./ \mathrm{m}^{2}\right)$ occurred on the dryland site in 1985 due to low, erratic precipitation. Stands evaluated in June 1986 on plots established with irrigation in 1985 had 38,46 , and 61 plants $/ \mathrm{m}^{2}$ for the untilled, disced, and DOC seedbeds, respectively. The disced or DOC seedbeds were required for successful $>10$ plants $\left./ \mathrm{m}^{2}\right)$ dryland seedings in 1986 at both locations. Irrigation the establishment year minimized risk of stand failure and allowed the use of any seedbed preparation or grass species studied. Sand bluestem was the only species to establish both years. However, if a dryland seeding of a cool-season species is desired, intermediate wheatgrass appeared more adapted than smooth brome.

Key Words: switchgrass, Panicum virgatum L., sand bluestem, Andropogon gerardii var. paucipilus (Nash) Fern., intermediate wheatgrass, Agropyron intermedium (Host) Beauv., Thinopyrum intermedium (Host) Barkw. \& D.R. Dewey subsp. intermedium, smooth brome, Bromus inermis Leyss., revegetation, seedbed

Upland sites in the Nebraska Sandhills, an edaphic Tallgrass Prairie, are sandy with low organic matter, low water-holding capacity, and low natural fertility while having a high erosion potential. Row crop cultivation under center pivot irrigation became a common practice in the 1970's. Many of these sites have been abandoned due to wind erosion, low crop yields, and/or poor economic conditions (Kocher and Stubbendieck 1986).

Seeding is difficult due to the soil characteristics and the intensity of weed competition. Longspine sandbur [Cenchrus longispinus (Hack.) Fern.] is the most prominent weed species on coarse sands. Discing stimulated longspine sandbur establishment on abandoned cropland in the Nebraska Sandhills (Roder et al. 1988, Kocher and Stubbendieck 1986, Oldfather 1984). Longspine sandbur allelopathy reduced switchgrass (Panicum virgatum L.) radicle elongation and may influence establishment (Roder et al. 1988). In

\footnotetext{
Authors are extension agricultura list, Hayes Center, Nebraska 69032; and professors, Department of Agronomy, University of Nebraska, Lincoln, Nebraska 68583. At the time of this research the senior author was a graduate research assistant.

Research was funded in part by a USDA competitive grant. Authors wish to thank Dr. Peter Demarco and Mr. Sid Salzman for providing the research sites, and Mr. John Gross for his contribution of time and seeding equipment. Use of proprietary name does not constitute endorsement by the Nebraska Agriculture Research Division. Published as Paper 8580, Journal Series, Nebraska Agriculture Research Division.

Manuscript accepted 1 December 1988.
}

Australia, living vegetative cover inhibited longspine sandbur establishment (Twentyman 1974). Irrigation could be used to reduce the moisture competition between weeds and seeded species during the seeding year.

The objectives of this study were to evaluate the effect of seedbed preparation on establishment of 2 warm-, and 2 cool-season grasses and on the weed population.

\section{Materials and Methods}

\section{Study Area}

Plots were established on 2 abandoned center pivot sites in the Nebraska Sandhills. One site in Custer County, near Milburn, was on a stream terrace of the Middle Loup River with an IpageValentine soil association (mixed, mesic Aquic Ustipsamment and mixed, mesic Typic Ustipsamment). The topography was level to slightly rolling. The second location was $11 \mathrm{~km}$ south of Ainsworth in Brown County approximately $50 \mathrm{~km}$ north of Milburn. The soil was a Valentine association (mixed, mesic Typic Ustipsamment) with rolling topography ( 9 to $17 \%$ slope).

Average annual precipitation is approximately $565 \mathrm{~mm}$ with 80\% of this occurring between April and September (Table 1).

Table 1. Preeipitation (mm) patterns for 1985 and 1986 at Milburn and Ainsworth, Nebraska1.

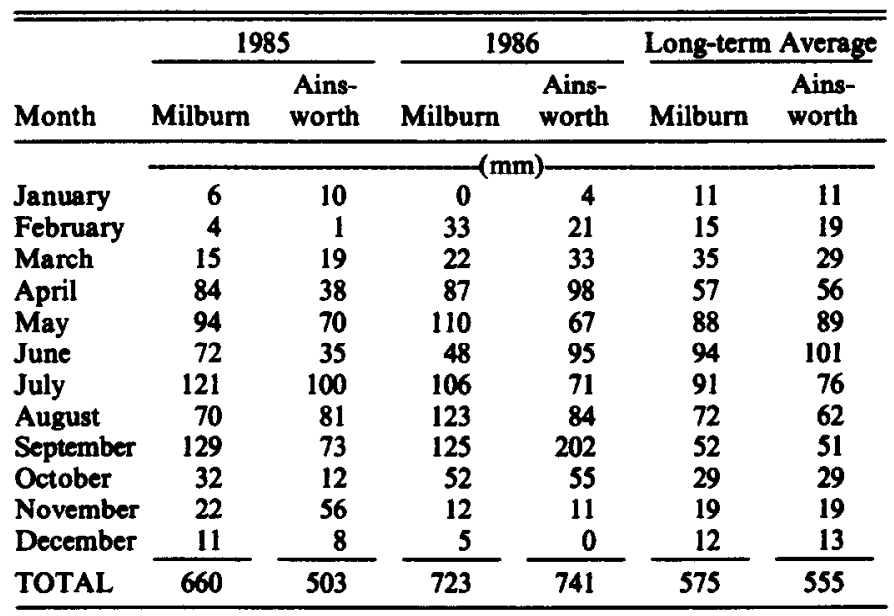

U.S. Department of Commerce. 1985. 1986. Climatol. Data. Nebraska. Nat. Oceanic Atmos. Admin. Environ. Data Information Service, Ashville, NC. The Anselmo, NE, records were used for Milburn. The long-term average is based on 1951-1980.

Snowfall occurs frequently from November to April, but snowcover is not continuous. The number of frost-free days ranges from 110 to 142 (U.S. Department of Agriculture 1982). The last spring frost $\left(0^{\circ} \mathrm{C}\right)$ can occur as late as 17 May with the first fall frost occurring as early as 5 September.

The principal annual weed at Milburn was longspine sandbur. Other problem weeds were spotted beebalm (Monarda pectinata L.), common lambsquarter (Chenopodium album L.), narrowleaf goosefoot, (Chenopodium desiccatum A. Nels.), redroot pigweed 
(Amaranthus retroflexus L.), smooth pigweed (Amaranthus hybridus L.), and common sunflower (Helianthus annuus L.). Longspine sandbur and green foxtail [Setaria viridus (L.) Beauv.] were the major weeds at Ainsworth, although horseweed [Conyza canadensis (L.) Cronq.] became a major problem the year following seeding.

The dominant climax species for both areas include sand bluestem [Andropogon gerardii var. paucipilus (Nash) Fern.], little bluestem [Schizachyrium scoparium (Michx.) Nash], prairie sandreed [Calamovilfa longifolia (Hook.) Scribn.], and needleandthread (Stipa comata Trin \& Rupr.). Switchgrass is often present, although it normally comprises less than $5 \%$ of the species composition by weight.

\section{Experiment Desien}

A randomized complete block design with 4 replications was used within each location year combination. A split block treatment arrangement was used with seedbed treatments as whole plots and grass species as subplots within seedbeds. Four large (36 $\times 72 \mathrm{~m}$ ) uniform areas were identified at each location. Each area was divided in half (block, $36 \times 36 \mathrm{~m}$ ) and seeding year, 1985 or 1986 , was randomly alloted. Within blocks, 3 seedbed treatments $(12 \times 36 \mathrm{~m})$ were randomly assigned. Seeded species were drilled in strips randomly assigned across all seed beds, resulting in $6 \times 12 \mathrm{~m}$ subplots. Experimental errors were tested for normality. Data with experimental errors that were not normally distributed and could not be transformed were excluded from the analysis of variance. Treatment main effects were tested using $F$ tests and orthogonal contrasts when interactions were not significant.

\section{Treatments \\ Seedbed Preparations}

Untilled (control), disced, and dead oat (Avena sativa $\mathrm{L}$.) cover (DOC) were the seedbed treatments. At Milburn, the untilled treatment had a mixture of annual and perennial grasses and broadleaf forbs from the previous year's growth. At Ainsworth, the untilled treatment had corn (Zea mays L.) residue and the previous year's fall-seeded, no-till rye (Secale cereale L.). Corn residue was heavy in low spots and interfered with seeding. The 1986 seedings used the same cover weathered for a year. Most of the weeds at both locations were actively growing at spring planting.

The disced seedbed treatment provided initial, temporary weed control. A tandem disc set to till at approximately $10 \mathrm{~cm}$ depth was used to partially incorporate plant residues. Residues were incorporated enough to reduce interference with seeding and seedling emergence while leaving enough cover to reduce the risk of wind and water erosion. Partial incorporation of corn residues was difficult on the lower areas at Ainsworth due to the large amounts present. Discing was done on 1 May 1985 and 1986.

The DOC seedbed treatment was disced $(10 \mathrm{~cm}$ depth) to partially incorporate residues on 23 March 1985 and 1986. Oats were planted 2 days later to stabilize the soil surface and suppress emergence of annual grasses and broadleaf weeds, providing a firm, relatively trash-free seedbed. Certified 'Ogle' oats were planted (54.5 kg PLS/ha) using a 3.7-m grain drill with $18 \mathrm{~cm}$ row spacings. On 1 May in both years, prior to perennial grass seeding, the oat standing crop was sprayed with glyphosate [N-(phosphonomethyl) glycine] at the rate of $1.1 \mathrm{~kg}$ ai/ha in a carrier volume of 1871 /ha. $\mathrm{A} \mathrm{CO}_{2}$-powered backpack sprayer equipped with a hand-held spray boom ( 8002 flat-fan spray tips) operated at $193 \mathrm{kPa}$ was used.

\section{Grass Species}

Two warm-season grasses: 'Goldstrike' sand bluestem and 'Trailblazer' switchgrass, and 2 cool-season grasses: 'Lincoln' smooth brome (Bromus inermis Leyss.) and 'Slate' intermediate wheatgrass [Thinopyrum intermedium (Host) Barkw. \& D.R.
Dewey subsp. intermedium] were seeded $(<2.5 \mathrm{~cm}$ depth, $18 \mathrm{~cm}$ row spacing) in monocultures using a 3.7-m Miller NoTill grass drill (3-point hitch) equipped with coulters, double-disc openers with depth bands and packer wheels. Seedings $\left(430 \mathrm{PLS} / \mathrm{m}^{2}\right)$ were made on 3, 4 May 1985 and on 3 May 1986. Optimum seeding time for warm-season grasses is approximately 1 April to 15 May. Development of the oat cover determined the date of grass seeding resulting in a relatively late date for cool-season grass seeding considering 1 March to 30 April as optimum.

The Milburn site was not irrigated. The Ainsworth site was irrigated ( $25 \mathrm{~mm} /$ week) in 1985 from 1 June to 15 August. In 1986, the center pivot system was removed by the cooperator. No weed control was practiced after planting in either year of the study at either location. Results were analyzed as 4 environments.

\section{Sampling}

The sampling area $(3 \times 9 \mathrm{~m})$ excluded a $1.5-\mathrm{m}$ border of each subplot. Density of seeded species in drill rows was determined on 10 randomly located $1-\mathrm{m}$ row lengths. Total seeded plants $/ \mathrm{m}$ was converted to density using row spacing to define area. Stand criteria were: failure ( $<5$ seedlings $/ \mathrm{m}^{2}$ ), marginal $\left(5-10\right.$ seedlings $/ \mathrm{m}^{2}$ ), successful $\left(>10\right.$ seedlings $/ \mathrm{m}^{2}$ ) (Launchbaugh 1966, Launchbaugh and Owensby 1978). Density of 3 nonseeded species categories (annual grasses, perennial grasses, and broadleaf forbs) was determined using 20 randomly located square frames $\left(0.1 \mathrm{~m}^{2}\right)$ in each subplot. Weed density data were not normally distributed and a natural logarithm transformation was used to normalize the data for treatment comparison. Areas seeded 3 May 1985 were sampled 9 June and 12 August 1985 and 15 June 1986. Areas seeded 3 May 1986 were sampled 15 June and 12 August 1986 and 10 June 1987.

\section{Results}

Annual precipitation at the Milburn site was above-normal both years (Table 1). However, during a 3-week period at the end of June and beginning of July 1985, environmental conditions were extreme. Generally, precipitation patterns in 1985 were characterized by intense rainfall events separated by long, dry periods; 1986 had a better precipitation distribution. Annual precipitation at Ainsworth was below normal in 1985 and above normal in 1986. Irrigation at the Ainsworth site in 1985 made it a much more moderate environment compared to Milburn. Both sites had similar annual precipitation in 1986. Grasshopper (Tettigoniidae sp.) damage to seedlings, especially smooth brome and intermediate wheatgrass was observed at both locations in both years of the study, particularly at Milburn in 1985 under water stress conditions.

\section{Milburn}

\section{Dryland-1985}

Broadleaf weed population was greater on the untilled seedbed, measured on 19 June, compared to tilled seedbeds (Table 2); however, the untilled seedbed had the lowest population of annual grasses present. The DOC seedbed preparation suppressed broadleaf weeds compared to discing while discing resulted in fewer nonseeded perennial grasses. Both seedbeds had high annual grass populations due to disturbance. These relationships among treatments were consistent during the growing season.

Excavation of seed and seedlings suggested that seed planted in the untilled treatment germinated, but most of the seedlings dried up before shoot emergence. The disced seedbed resulted in the highest seedling emergence measured on 19 June 1985 for all species planted compared to the DOC (Table 3). Seedling losses were high ( $90 \%$ of $19 \mathrm{June}$ stand) during the year of establishment. Overwinter losses reduced seedling stand density to less than 5 plants/ $\mathrm{m}^{2}$ by 15 June 1986 for both disced and DOC seedbeds.

Initial warm-season grass (sand bluestem and switchgrass) density was lower than cool-season grass (smooth brome and interme- 
Table 2. Erfect of seedbed preparation on the dencity (plants/ $\mathrm{m}^{2}$ ) of annual grasses, perennial grasses, and broadleaf weeds at 2 sampling dates in 2 seeding years at Milburn and Ainsworth1.

\begin{tabular}{|c|c|c|c|c|}
\hline \multirow[b]{4}{*}{ Seedbed preparation Plant type } & \multicolumn{4}{|c|}{ Planting dates } \\
\hline & \multicolumn{2}{|c|}{ 3, 4 May 1985} & \multicolumn{2}{|c|}{3 May 1986} \\
\hline & \multicolumn{4}{|c|}{ Sampled } \\
\hline & $\begin{array}{l}19 \text { June } \\
1985\end{array}$ & $\begin{array}{c}12 \text { Aug } \\
1985\end{array}$ & $\begin{array}{c}15 \text { June } \\
1986 \\
\end{array}$ & $\begin{array}{r}12 \mathrm{Aus} \\
1986 \\
\end{array}$ \\
\hline & . & $\begin{array}{r}\text { - (plants } \\
\text { Milb } \\
\text { dryls }\end{array}$ & $\begin{array}{l}\left.s / \mathrm{m}^{2}\right)- \\
\text { urn } \\
\text { and- }\end{array}$ & \\
\hline $\begin{array}{l}\text { Untilled } \\
\text { Disced } \\
\text { Dead oat cover } \\
\text { (DOC) }\end{array}$ & $\begin{array}{r}3 \\
81 \\
83\end{array}$ & $\begin{array}{r}7 \\
62 \\
86\end{array}$ & $\begin{array}{r}65 \\
219 \\
156\end{array}$ & $\begin{array}{l}24 \\
87 \\
63\end{array}$ \\
\hline \multicolumn{5}{|l|}{ Contrasts $(\mathrm{P}>\mathrm{F})$} \\
\hline $\begin{array}{l}\text { Untilled vs. tilled } 2 \\
\text { Disced vs. DOC }\end{array}$ & $\begin{array}{r}<.01 \\
.96\end{array}$ & $\begin{array}{r}<.01 \\
.18\end{array}$ & $\begin{array}{r}<.01 \\
.11\end{array}$ & $\begin{array}{r}<.01 \\
.15\end{array}$ \\
\hline $\begin{array}{l}\text { Untilled } \\
\text { Disced } \\
\text { DOC }\end{array}$ & $\begin{array}{l}61 \\
20 \\
63\end{array}$ & $\begin{array}{r}122 \\
34 \\
108\end{array}$ & $\begin{array}{l}98 \\
59 \\
83\end{array}$ & $\begin{array}{l}162 \\
174 \\
233\end{array}$ \\
\hline \multicolumn{5}{|l|}{ Contrasts $(P>F)$} \\
\hline $\begin{array}{l}\text { Untilled vs. tilled } \\
\text { Disced vs. DOC }\end{array}$ & $\begin{array}{l}<.01 \\
<.01\end{array}$ & $\begin{array}{r}.01 \\
<.01\end{array}$ & $\begin{array}{l}.11 \\
.11\end{array}$ & $\begin{array}{l}.24 \\
.15\end{array}$ \\
\hline $\begin{array}{l}\text { Untilled } \\
\text { Disced } \\
\text { DOC }\end{array}$ & $\begin{array}{r}340 \\
67 \\
24\end{array}$ & $\begin{array}{l}76 \\
45 \\
19\end{array}$ & $\begin{array}{l}43 \\
82 \\
57\end{array}$ & $\begin{array}{l}17 \\
53 \\
40\end{array}$ \\
\hline \multicolumn{5}{|l|}{ Contrasts $(P>F)$} \\
\hline \multirow[t]{2}{*}{$\begin{array}{l}\text { Untilled vs. tilled } \\
\text { Disced vs. DOC }\end{array}$} & $\begin{array}{l}<.01 \\
<.01\end{array}$ & $\begin{array}{l}.03 \\
.01\end{array}$ & $\begin{array}{l}.21 \\
.37\end{array}$ & $\begin{array}{r}<.01 \\
.36\end{array}$ \\
\hline & \multicolumn{4}{|c|}{$\begin{array}{l}\left.\text {-(plants } / \mathrm{m}^{2}\right) \\
\text { Ainsworth } \\
\text { ted- }\end{array}$} \\
\hline $\begin{array}{l}\text { Untilled } \\
\text { Disced } \\
\text { DOC }\end{array}$ & $\begin{array}{l}128 \\
189 \\
137\end{array}$ & $\begin{array}{l}125 \\
169 \\
125\end{array}$ & $\begin{array}{r}556 \\
1075 \\
854\end{array}$ & $\begin{array}{l}399 \\
837 \\
578\end{array}$ \\
\hline \multicolumn{5}{|l|}{ Contrast $(\mathrm{P}>\mathrm{F})$} \\
\hline $\begin{array}{l}\text { Untilled vs. tilled } \\
\text { Disced vs. DOC }\end{array}$ & $\begin{array}{l}.31 \\
.23\end{array}$ & $\begin{array}{l}.41 \\
.19\end{array}$ & $\begin{array}{r}<.01 \\
.11\end{array}$ & $\begin{array}{r}<.01 \\
.05\end{array}$ \\
\hline $\begin{array}{l}\text { Untilled } \\
\text { Disced } \\
\text { DOC }\end{array}$ & $\begin{array}{l}1 \\
<1\end{array}$ & $\begin{array}{l}<1 \\
<1 \\
<1\end{array}$ & $\begin{array}{r}255 \\
15 \\
24\end{array}$ & $\begin{array}{r}200 \\
17 \\
18\end{array}$ \\
\hline \multicolumn{5}{|l|}{ Contrast $(P>F)$} \\
\hline $\begin{array}{l}\text { Untilled vs. tilled } \\
\text { Disced vs. DOC }\end{array}$ & $\begin{array}{l}.31 \\
.60\end{array}$ & $\begin{array}{l}.63 \\
.94\end{array}$ & $\begin{array}{r}<.01 \\
.42\end{array}$ & $\begin{array}{r}<.01 \\
.88\end{array}$ \\
\hline
\end{tabular}

Orthogonal comparison were made on the natural log transformations. 2Tilled is the average response of the disced and dead oat cover (DOC) seedbed treatments.

diate wheatgrass) density on 19 June 1985 (Table 4). However, by 1 July 1985 (data not shown) few cool-season seedlings could be found, and by 12 August 1985 none were observed white sand bluestem seedlings were abundant $\left(23 / \mathrm{m}^{2}\right)$. By June 1986 , seedling density of warm- and cool-season grasses was not different and only sand bluestem met the requirement for a marginal stand.

\section{Dryland-1986}

In contrast to the 1985 seeding, the untilled seedbed had fewer broadleaf weeds than the disced or DOC seedbed preparations in June (Table 2). Few annual grasses were found on the untilled seedbed in June and August.

The untilled seedbed had a lower seedling emergence than the disced or DOC seedbeds (Table 3). Emergence on the untilled seedbed was nearly 15-fold better than in 1985; however, summer mortality was severe. At the end of the first growing season only the
Table 3. The effect of seedbed preparation averaged over seeded species on stand dencity (plants/m2) at 3 campling dates at Milbum and Alnsworth for plots seeded 3,4 May 1985 and 3 Mny 1926.

\begin{tabular}{|c|c|c|c|c|c|c|}
\hline \multirow[b]{3}{*}{ Seedbed preparation } & \multicolumn{6}{|c|}{ Planting dates } \\
\hline & \multicolumn{3}{|c|}{ 3, 4 May 1985} & \multicolumn{3}{|c|}{3 May 1986} \\
\hline & $\begin{array}{l}19 \text { June } \\
1985\end{array}$ & $\begin{array}{l}12 \text { Aug } \\
1985\end{array}$ & $\begin{array}{l}15 \text { June } \\
1986\end{array}$ & $\begin{array}{l}15 \text { June } \\
1986\end{array}$ & $\begin{array}{l}12 \text { Aug } \\
1986\end{array}$ & $\begin{array}{l}10 \text { June } \\
1987\end{array}$ \\
\hline & & & $\begin{array}{r}\text { (plant } \\
\text { Mill }\end{array}$ & $\begin{array}{l}\left.\mathrm{ts} / \mathrm{m}^{2}\right)- \\
\text { burn }\end{array}$ & & \\
\hline $\begin{array}{l}\text { Untilled } \\
\text { Disced } \\
\text { Dead oat cover } \\
\text { (DOC) }\end{array}$ & $\begin{array}{r}4 \\
151 \\
122\end{array}$ & $\begin{array}{l}<1 \\
14 \\
12\end{array}$ & $\begin{array}{r}<1 \\
3 \\
2\end{array}$ & $\begin{array}{r}55 \\
174 \\
175\end{array}$ & $\begin{array}{r}3 \\
24 \\
31\end{array}$ & $\begin{array}{r}2 \\
14 \\
19\end{array}$ \\
\hline \multirow[t]{2}{*}{$\begin{array}{l}\text { Contrasts (P>F) } \\
\text { Untilled vs. tilled }{ }^{2} \\
\text { Disced vs. DOC }\end{array}$} & .05 & $\overline{.87}$ & .37 & $\begin{array}{l}.01 \\
.92\end{array}$ & .19 & .54 \\
\hline & \multicolumn{6}{|c|}{ Ainsworth } \\
\hline $\begin{array}{l}\text { Untilled } \\
\text { Disced } \\
\text { DOC } \\
\text { Contrasts }(P>F)\end{array}$ & $\begin{array}{r}92 \\
117 \\
106\end{array}$ & $\begin{array}{l}57 \\
64 \\
86\end{array}$ & $\begin{array}{l}38 \\
46 \\
61\end{array}$ & $\begin{array}{l}52 \\
56 \\
67\end{array}$ & $\begin{array}{r}5 \\
25 \\
31\end{array}$ & $\begin{array}{r}3 \\
11 \\
13\end{array}$ \\
\hline $\begin{array}{l}\text { Untilled vs. tilled } \\
\text { Disced vs. DOC }\end{array}$ & $\begin{array}{l}.07 \\
.37\end{array}$ & $\begin{array}{l}.15 \\
.14\end{array}$ & $\begin{array}{l}.03 \\
.04\end{array}$ & $\begin{array}{l}.01 \\
.02\end{array}$ & .18 & .49 \\
\hline
\end{tabular}

'Species seeded were sand bluestem, switchgrass, smooth brome, and intermediate wheatgrass.

${ }^{2}$ Tilled is the average response of the disced and dead oat cover (DOC) seedbed treatments.

${ }^{3}$ The untilled seedbed was not included in the analyses of variance due to non-normal distributions.

disced and DOC seedbeds had successful stands. Winterkill reduced the stands about $50 \%$, but stands were rated successful. Due to the high rate of switchgrass emergence, warm-season grasses had a higher seedling density in June than cool-season grasses (Table 4). Summer mortality was severe, especially for cool-season grasses. Following the first winter there was no difference in cool- and warm-season grass densities due to some apparent winterkill of warm-season grasses and tillering of cool-season grasses. Sand bluestem had a higher second-year stand than switchgrass while the 2 cool-season grasses were similar with all 4 species having successful stands.

\section{Ainsworth \\ Irrigated-1985}

Irrigation was applied during the growing season at approximately $25 \mathrm{~mm} /$ week from June to August 1985. Annual grasses, primarily foxtail, were the dominant nonseeded species on all seedbeds (Table 2). Broadleaf weeds were not important and the nonseeded species density remained unchanged during the growing season.

Seedling emergence data were variable on the untilled seedbed due to heavy crop residues which interfered with seed placement and seedling emergence (Table 3). Seedling emergence was greater and more uniform on the disced and DOC than on the untilled seedbed. By August 1985, 38, 45, and $18 \%$ of the original seedling stand had died on the untilled, disced, and DOC seedbeds, respectively. Overwinter survival was good on all seedbeds with all second year stands rated successful.

Both warm- and cool-season grasses established at acceptable densities with irrigation (Table 4). Average cool-season grass density was greater than warm-season grass density on all sample dates. Seedling density for all species declined to less than $50 \%$ of June 1985 stands by June 1986 . There was no significant difference between sand bluestem and switchgrass seedling density. However, sand bluestem plants appeared to be more vigorous than the switchgrass plants. Average cool-season grass density was about 3-fold greater than warm-season grasses after the first winter. 
Table 4. Seedling dendty (plants $/ \mathrm{m}^{2}$ ) over seedbed preparations at 3 sampling dates for grasses seeded at Milburn and Ainsworth for plots seeded 3, 4 May. 1985 and 3 May 1986.

\begin{tabular}{|c|c|c|c|c|c|c|}
\hline \multirow[b]{3}{*}{ Seeded species } & \multicolumn{6}{|c|}{ Planting dates } \\
\hline & \multicolumn{3}{|c|}{ 3, 4 May 1985} & \multicolumn{3}{|c|}{3 May 1986} \\
\hline & $\begin{array}{l}\text { 19 June } \\
1985\end{array}$ & $\begin{array}{c}12 \text { Aug } \\
1985\end{array}$ & $\begin{array}{l}15 \text { June } \\
1986\end{array}$ & $\begin{array}{c}15 \text { June } \\
1986\end{array}$ & $\begin{array}{l}12 \text { Aug } \\
1986\end{array}$ & $\begin{array}{l}10 \text { June } \\
1987\end{array}$ \\
\hline & \multicolumn{5}{|c|}{$-\left(\right.$ plants $\left./ \mathrm{m}^{2}\right)$} & Milburn \\
\hline $\begin{array}{l}\text { Sand bluestem } \\
\text { Switchgrass } \\
\text { Smooth brome } \\
\text { Intermediate } \\
\text { wheatgrass }\end{array}$ & $\begin{array}{r}163 \\
83 \\
158 \\
141\end{array}$ & $\begin{array}{r}24 \\
3 \\
<1 \\
<1\end{array}$ & $\begin{array}{l}6 \\
1 \\
2 \\
2\end{array}$ & $\begin{array}{l}132 \\
171 \\
126 \\
110\end{array}$ & $\begin{array}{r}37 \\
58 \\
6 \\
9\end{array}$ & $\begin{array}{l}24 \\
10 \\
14 \\
18\end{array}$ \\
\hline \multicolumn{7}{|l|}{ Contrasts $(P>F)$} \\
\hline $\begin{array}{l}\text { Sand bluestem vs. } \\
\text { switchgrass }\end{array}$ & $<.01 t$ & .051 & $<.011$ & .05 & .10 & $<.01^{1}$ \\
\hline $\begin{array}{l}\text { Smooth brome vs. } \\
\text { intermediate } \\
\text { wheatgrass }\end{array}$ & .29 & $\longrightarrow$ & .75 & .40 & .80 & .27 \\
\hline \multirow{2}{*}{$\begin{array}{l}\text { Warm-season vs. } \\
\text { cool-season }{ }^{3}\end{array}$} & .03 & -2 & .18 & .03 & $<.01$ & .75 \\
\hline & \multicolumn{6}{|c|}{ Ainsworth } \\
\hline Sand bluestem & 77 & 70 & 33 & 49 & 49 & 16 \\
\hline Switchgrass & 40 & 33 & 17 & 44 & 28 & 9 \\
\hline Smooth brome & 143 & 61 & 56 & 79 & 26 & 9 \\
\hline $\begin{array}{l}\text { Intermediate } \\
\text { wheatgrass }\end{array}$ & 159 & 113 & 88 & 94 & 85 & 12 \\
\hline \multicolumn{7}{|l|}{ Contrasts $(P>F)$} \\
\hline $\begin{array}{l}\text { Sand bluestem vs. } \\
\text { switchgrass }\end{array}$ & .04 & .03 & .28 & .49 & .01 & $.27^{1}$ \\
\hline $\begin{array}{l}\text { Smooth brome vs. } \\
\text { intermediate } \\
\text { wheatgrass }\end{array}$ & .31 & $<.01$ & .04 & .05 & .03 & .65 \\
\hline $\begin{array}{c}\text { Warm-season vs. } \\
\text { cool-season }\end{array}$ & $<.01$ & $<.01$ & $<.01$ & $<.01$ & $<.01$ & .69 \\
\hline
\end{tabular}

The untilled seedbed was not included in the analyses of variance due to non-normal distributions.

2Smooth brome and intermediate wheatgrass were not included in the analysis of variance to non-normal distributions.

${ }^{3}$ Warm-season is the average response of sand bluestem and switchgrass. Cool-season is the average response of smooth brome and intermediate wheatgrass.

Intermediate wheatgrass appeared to be more vigorous than smooth brome; however, a higher percentage of smooth brome survived the winter. Intermediate wheatgrass plants produced abundant reproductive tillers in the spring of 1986 while very few smooth brome plants produced reproductive tillers.

\section{Dryland-1986}

The untilled seedbed had lower annual grass population than the tilled seedbeds (Table 2). However, broadleaf weeds (primarily horseweed) had a much higher density on the untilled seedbed compared to the tilled seedbeds. Generally, nonseeded species densities were greater in 1986 than in 1985.

Seedling emergence was highest on the DOC seedbed (Table 3). However, emergence on both the untilled and the disced seedbeds exceeded 50 seedlings $/ \mathrm{m}^{2}$. Approximately $50 \%$ of the original seedling stand had died by August 1986 on the disced and DOC seedbeds compared to a $90 \%$ loss of seedlings on the untilled seedbed. By 10 June 1987, seedling density on the untilled seedbed was low and variable. Seedling densities on the disced and DOC seedbeds were rated successful.

Warm-season grass emergence was lower than cool-season grass in June 1986 (Table 4). There was no difference in emergence between the warm-season grasses. Intermediate wheatgrass had greater emergence than smooth brome. Summer mortality was most evident in switchgrass and smooth brome. There were no significant differences in seedling density between sand bluestem and switchgrass, or between smooth brome and intermediate wheatgrass by June 1987 .

\section{Discussion and Conclusions}

Dryland establishment of forage grasses was inconsistent, supporting the findings of McGinnies (1960), Barnes et al. (1952), and Sumner and Love (1961). In 1985 forage grasses did not establish on the dryland seeding at Milburn, regardless of seedbed treatment. Apparently low precipitation, moisture competition from an actively growing nonseeded species population at the time of seeding, and crop residue interfering with seed placement resulted in stand failure. However, in $\mathbf{1 9 8 6}$ when moisture was more favorable for emergence, dryland seedings at both Milburn and Ainsworth were successful.

Successful grass stands were obtained at Ainsworth in 1985 with irrigation on all seedbed treatments, even though nonseeded species populations were high $\left(>100\right.$ plants $\left./ \mathrm{m}^{2}\right)$. Irrigated grass seedlings were more competitive with nonseeded species. Oldfather (1984) also noted improved seedling establishment with supplemental irrigation the year of establishment.

Dryland seedings using the untilled treatment were not successful. Improved seedling emergence on the shallow-tilled seedbeds was apparently due to a firmer seedbed, better seed placement and removal of weedy competition compared to the untilled seedbed. This compensated for the subsequent flush of annual grasses following disturbance. The DOC seedbed should be used under dryland conditions in preference to the disced seedbed. The DOC seedbed is the most expensive of the 3 seedbeds used, but apparently the combination of chemically killed mulch which protected against wind erosion and the additional equipment passes which resulted in a firmer seedbed provided better seedling establishment.

Dryland seeding of switchgrass, smooth brome, or intermediate wheatgrass resulted in stand failure at Milburn in 1985. Most seedling mortality occurred from 20 June to 10 July when temperatures were near $38^{\circ} \mathrm{C}$ with windy conditions and no precipitation. Sand bluestem was the only species with a marginal stand (5-10 seedlings $/ \mathrm{m}^{2}$ ). The dryland seedings of 1986 were successful for all species at both locations due to a more favorable year.

With irrigation, sand bluestem, switchgrass, smooth brome, and intermediate wheatgrass stands were successful 1 year after planting. Smooth brome and intermediate wheatgrass seedling emergence with irrigation was greater than sand bluestem and switchgrass, which agreed with earlier observations by Depuit et al. (1982). Intermediate wheatgrass, the most successful species, developed a canopy which shaded out weeds such as longspine sandbur and green foxtail, which appeared to support research by Twentyman (1974). In addition, intermediate wheatgrass was the only 1 of the 4 species to produce reproductive tillers 1 year after seeding.

\section{Literature Cited}

Barnes, O.K., R.L. Lang, and A.A. Beetle. 1952. Grass establishment on Wyoming dryland. Wyoming Agr. Exp. Sta. Bull. 314.

Depuit, E.J., C.L. Skilbred, and J.G. Coenbere. 1982. Effects of two years of irrigation on revegetation of coal surface-mined land in Southeastern Montana. J. Range Manage. 35:67-73.

Kocher, E., and J. Stubbendieck. 1986. Broadcasting grass seed to revegetate sandy soils. J. Range Manage. 39:555-557.

Launchbaugh, J.L. (ed.). 1966. A stand establishment survey of grass plantings in the Great Plains. Nebraska Agr. Exp. Sta. Great Plains Counc. Pub. 23.

Launchbaugh, J.L., and C.E. Owensby. 1978. Kansas rangelands-their management based on a half century of research. Kansas Agr. Exp. Sta. Bull 622. 
MeGinnies. W.J. 1960. Effects of moisture stress and temperature on germination of six range grasses. Agron. J. 52:159-162.

Oldinther, S.S. 1984. Reseeding abandoned cropland in the Nebraska Sandhills. M.S. Thesis, Univ. Nebraska, Lincoln.

Roder, W., S.S. Waller, and J.L. Stubbendieck. 1988. Allelopathic effects of sandbur leachate on switchgrass germination:observations. J. Range Manage. 41:86-87.
Sumner, D.C., and R. Merton Love. 1961. Seedling competition from resident range cover often cause of seedling failures. California Agr. 15:6-7.

Twentyman, J.D. 1974. Environmental control of dormancy and germination in the seeds of Cenchrus longispinus (Hack.) Fern. Weed Res. 14:1-11.

U.S. Department of Agriculture. 1982. Soil survey of Custer County. Soil Conserv. Serv., Washington, D.C. 